\title{
Editorial \\ Publisher's Note: Continued Publication of Current Issues in Molecular Biology by MDPI
}

\author{
Franck Vazquez *(D) and Shu-Kun Lin (D) \\ MDPI, St. Alban-Anlage 66, CH-4052 Basel, Switzerland; lin@mdpi.com \\ * Correspondence: vazquez@mdpi.com
}

check for

updates

Citation: Vazquez, F.; Lin, S.-K. Publisher's Note: Continued Publication of Current Issues in Molecular Biology by MDPI. Curr. Issues Mol. Biol. 2021, 43, 1. https://doi.org/10.3390/ cimb43010001

Received: 10 March 2021 Accepted: 10 March 2021 Published: 18 March 2021

Publisher's Note: MDPI stays neutral with regard to jurisdictional claims in published maps and institutional affiliations.

Copyright: (c) 2021 by the authors. Licensee MDPI, Basel, Switzerland. This article is an open access article distributed under the terms and conditions of the Creative Commons Attribution (CC BY) license (https:/ / creativecommons.org/licenses/by/ $4.0 /)$.
Current Issues in Molecular Biology (ISSN 1467-3045) was launched in 1999 and has published international and multidisciplinary articles on all aspects of molecular biology spanning from basic mechanisms to applications in fields primarily, but not exclusively, relevant to microbiology and virology. Current Issues in Molecular Biology, published by Caister Academic Press [1] over the past 23 years, has been the home for 388 peer-reviewed articles across 42 volumes. As of 5 March 2021, Current Issues in Molecular Biology will be published by MDPI [2].

We are delighted to take over the publication of Current Issues in Molecular Biology, as it excellently complements the portfolio of MDPI journals [3], provides a multidisciplinary addition to our existing journals in this field, such as the International Journal of Molecular Sciences [4] and strengthens our service to the relevant scientific communities.

Current Issues in Molecular Biology will publish papers which provide fundamental mechanistic and functional insights into molecular biology, in both eukaryotes and prokaryotes. MDPI will publish three issues in 2021, and four quarterly issues as of 2022.

We look forward to publishing your work in Current Issues in Molecular Biology!

Conflicts of Interest: The authors declare no conflict of interest.

\section{References}

1. Current Issues in Molecular Biology Previous Home Page. Available online: http://web.archive. org/web / 20210304013827/https: / / www.caister.com/cimb / (accessed on 5 March 2021).

2. Current Issues in Molecular Biology New Home Page. Available online: https://www.mdpi.com/ journal/cimb (accessed on 5 March 2021).

3. MDPI's Journals List. Available online: https://www.mdpi.com/about/journals (accessed on 8 March 2021).

4. International Journal of Molecular Sciences Home Page. Available online: https://www.mdpi. $\mathrm{com} /$ journal/ijms (accessed on 8 March 2021). 